through the ordeal; and his work may truly be said to be indispensable, not only to the palæontologist, but likewise to every student of zoology who desires to know something more of his subject than can be gleaned from the study of the animals of the present day.

R. L.

\section{THE SUNSHINE OF LONDON.}

FOR some few years past sunshine recorders have been in operation at four stations situated in various parts of London; and in attempting to gain some idea as to the average duration of sunshine in the metropolis, one is met at the outset by the somewhat perplexing question as to which of these four is best calculated to yield a fair result. One recorder is placed in the heart of the City, at Bunhill Row ; and exposed as it is to a maximum amount of smoke and fog there can be little hesitation in saying that its indications are, for the metropolis as a whole, greatly below the mark. Another is stationed somewhat more favourably at Westminster, on the roof of the Meteorological Office, but even there the influence of the surrounding chimneys is felt to a very serious extent, and many a fair winter's day has been known to pass without the registration of so much as a trace of bright sunshine. In a third instance the conditions are reversed, for at the Kew Observatory the air is almost as free from smoke and mist as it is in the open country, so that as a London record the sunshine instrument gives us too high a value. The fourth station appears, however, to be one which strikes a fairly even balance between the meteorological features of the City and those of the more open suburbs ; for, although Greenwich is influenced to a greater extent by the impurities of London than Kew, it is sufficiently removed from the central parts of the metropolis to escape much of the fog and smoke which affect the recording instruments both in the City and at Westminster. From a careful examination, we are inclined to think that the Greenwich record supplies a very fair idea of the conditions which prevail over the metropolis as a whole ; and as the observations of bright sunshine have now been made at the Royal Observatory for rather over fourteen years, sufficient material has accumulated for the deduction of average results. It is only such sunshine as is strong enough to burn the papers that is here dealt with.

The general results of an examination of the Greenwich records for the fourteen years 1877 to 1890 are given in the following table, which shows for each month, for each season, and for the entire year--firstly, the average number of hours of bright sunshine ; secondly, the percentage of the possible amount ; thirdly, the average number of hours per day ; fourthly, the average amount of sunshine on the brightest day; and fifthly, the number of days on which no bright sunshine was registered. The spring season comprises the months of March, April, and May; the summer those of June, July, and August; the autumn those of September, October, and November; and the winter those of December, January, and February.

From an examination of the table we see that the sunniest month in the year is May, with a total of 179 hours, or 37 per cent. of the possible quantity. June, however, runs it very close with a total of 174 hours, or 35 per cent. of the possible; and, in fact, owing to the slight difference which exists between the length of the two months, the daily average (five hours and threequarters) is the same in each. It is a somewhat singular fact that the sunniest individual month in the course of the whole fourteen years was neither May nor June,but July. In the July of $\mathrm{s} 887$ the aggregate number of hours recorded was 277 , or 56 per cent. of the possible quantity, the daily average being very nearly nine hours. In both May and June we may look for at least one day with brilliant sunshine continuing for about I 3 hours, but on an average there are in each month three days on which the solar rays are alto- gether absent. As regards sunless days, July is the most highly favoured month, for on an average of fourteen years' observations there is then only one day that is continuously overcast. The finest day experienced in the course of the entire period was June I3, I887, when no less than $\mathrm{I}_{5}$ hours of bright sunshine were recorded.

\begin{tabular}{|c|c|c|c|c|c|c|c|}
\hline \multicolumn{3}{|l|}{ Months. } & 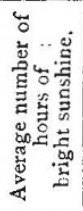 & 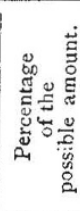 & 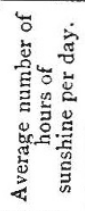 & 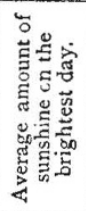 & 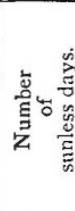 \\
\hline January $\quad \ldots$ & $\ldots$ & & 26 & 10 & 0.8 & $5 \%$ & 19 \\
\hline February ... & $\ldots$ & $\ldots$ & 42 & 15 & I. 5 & 6.9 & 12 \\
\hline March $\ldots$ & $\ldots$ & $\ldots$ & 95 & 26 & $3 \circ$ & $8 \cdot 9$ & 6 \\
\hline April ... ... & $\ldots$ & $\ldots$ & 122 & 29 & $4 \cdot 1$ & II 0 & 4 \\
\hline May ... ... & $\ldots$ & $\ldots$ & 179 & 37 & 58 & 13.0 & 3 \\
\hline June ... & $\ldots$ & $\ldots$ & 174 & 35 & $5 \cdot 8$ & J 3.1 & 3 \\
\hline July .... & $\ldots$ & $\ldots$ & I 67 & 34 & 54 & $\times 2.5$ & I \\
\hline August $\quad \ldots$ & $\ldots$ & $\ldots$ & 154 & 34 & $5^{\circ} 0$ & II $\cdot 6$ & 2 \\
\hline September & $\ldots$ & $\ldots$ & I 15 & 31 & $3 \cdot 8$ & $10 \cdot 1$ & 3 \\
\hline October $\quad \ldots$ & $\ldots$ & $\ldots$ & 77 & 23 & $2 \cdot 5$ & $7 \cdot 8$ & 9 \\
\hline November & $\ldots$ & $\ldots$ & 43 & 16 & I. 4 & $5 \cdot 8$ & 12 \\
\hline December & $\ldots$ & $\ldots$ & 20 & 8 & 0.7 & 39 & 20 \\
\hline The Spring & $\ldots$ & $\ldots$ & 396 & $3 \mathrm{I}$ & $4 \cdot 3$ & $13 \cdot 2$ & 12 \\
\hline The Summer & $\ldots$ & $\ldots$ & 495 & 34 & 5.4 & 13.2 & 6 \\
\hline The Autumn & $\ldots$ & $\ldots$ & 235 & 24 & $2 \cdot 6$ & IO. I & 25 \\
\hline The Winter & $\ldots$ & $\ldots$ & 89 & II & 10 & $7 \circ 0$ & 50 \\
\hline \multicolumn{2}{|c|}{ The entire Year } & $\ldots$ & I 2 I 4 & 27 & $3 \cdot 3$ & 13.7 & 94 \\
\hline
\end{tabular}

The dullest month of the year is December, with a total of only 20 hours of sunshine, or 8 per cent. of the possible, and with 20 sunless days. January is very little better, the total number of hours being then 26 , or Io per cent. of the possible, and with an average of 19 sunless days. In each of these winter months the daily average of sunshine is only about three-quarters of an hour, but after January the weather rapidly improves, February being twice as sunny as its predecessor, and March twice as sunny as February. The dullest month in the course of the whole fourteen years was last December, when the total duration of sunshine was less than two hours and a half, or about I per cent. of the possible amount. On 28 days there was a complete absence of sunshine, and of these 28 no fewer than 18 were consecutive. On the brightest December day we can hardly expect four hours of sunshine, but we may certainly look for more than we had last December, when the finest day produced less than an hour and a half.

Turnirg to the various seasons we find, as we might expect, that the maximum amount of sunshine is recorded in the summer, the average number of hours being 495 , or 34 per cent. of the possible amount. The finest summer of the whole fourteen years was the Jubilee season of 1887 , when there were 7 I 5 hours, or about 50 per cent. of the possible. The dullest summer of the entire series was that of the following year (1888), when the total number of hours was only 373 , or 26 percent. of the possible. The average number of sunless days in the summer months is only six, but in 1888 there were 16 , or six more than in any other year of the series. The spring is of course far more sunny than the autumn, the total amount of sunshine in the former season being 396 hours, as against 235 in the latter. In the winter the aggregate amount is only 89 hours, or an average of about one hour per day. The number of sunless days advances from the sunniest to the dullest of the seasons in fairly ap-

NO. I I 4 , VOL. 43] 
proximate geometrical progression, being twice as great in spring as in summer, twice as great in autumn as in spring, and twice as great in winter as in autumn. In a London winter there are more days without sunshine than with it.

The values for the entire year show that the average number of hours of bright sunshine is 1214 , or 27 per cent. of the possible amount. The largest number recorded in any year of the fourteen was in 1887, when there were 1407 , while the smallest was in that notoriously dismal year 1879 , when there were only 984 . Taking the year through, the average daily amount of sunshine at Greenwich is little more than three hours and a quarter, or less than half the quantity possible on the shortest December day. Thus, if the sun were to shine all the year through for the same number of hours as the highest possible in mid winter, we should get twice as much bright weather as we actually experience ; and the results of an average of fourteen years' observations show that there are 94 days out of the 365 , or more than a fourth of the year, upon which the solar rays are either altogether absent or are too feeble to leave any mark on the recording instrument.

FREDK. J. BRODIE.

\section{NOTES.}

AT a meeting of the Academy of Sciences held in Paris on Monday, the 2nd inst., Mr. Archibald Geikie, F.R.S., DirectorGeneral of the Geological Survey of the United Kingdom, was elected Correspondent of the Institute of France.

ON March I a meeting was held in the large hall of the Berlin Rathhaus to do honour to the memory of Dr. Schliemann. The meeting was summoned by the Geographical, the Anthropological, and the Archæological Societies of Berlin. Profs. Virchow and Curtius were the chief speakers, and they eulogized the character and achievements of the famous explorer and archæologist.

THE office of Colonial Bacteriologist at the Cape of Good Hope, has been offered to Dr. Edington of the University of Edinburgh.

RePLying to Mr. John Ellis in the House of Commons, on Tuesday, Mr. Plunket said that the official guide to the Royal Gardens at Kew, which was at present out of print, was under revision. During the last two years the changes consequent on the rearrangement of the collections had been so extensive, that it had been thought better to suspend the publication of the guide, as in such a period of transition it would mislead, and be a cause of disappointment. Now that the rearrangement of the collections was nearing completion, a new guide had been put in hand, and $\mathrm{Mr}$. Thiselton Dyer hoped to have it ready by next summer.

WE regret to have to record the death of Mr. George Bertin, who was well known as an able and learned student of Assyriology. He died on February $\mathrm{I} 8$, in his forty-third year.

PROF. VICTOR HORSLEY will give a discourse at the Royal Institution on "Hydrophobia," on Friday, March 20, in place of Prof. W. E. Ayrton, who is unable at present to give his promised lecture on "Electric Meters, Motors, and Money Matters."

ON Friday last, Mr. Goschen received a numerous deputation representing the University Colleges of England, who presented a memorial in favour of the annual grant, which is now $£ \mathrm{I}_{5}, 000$, being increased. The deputation was intrcduced by Mr. Chamberlain, who, with Mr. Mundella, Sir Henry Roscoe, and others, strongly supported the memorial. Mr. Goschen, in the course of his reply, said they would not expect him without con. sultation with his colleagues, or at once after the reception of a deputation such as that, to give any final answer, but he was

$$
\text { NO. I I I } 4 \text {, vOL. 43. }
$$

disposed to admit that in many ways they had made out a strong case. At all events they had made out this case, that the Colleges had been doing an increased good work, and that they thought that with additional sums they would be able to widen still the area of their usefulness. One point had struck him while the discussion was going on-and he might some time discuss it with Mr. Chamberlain, who would be a good authority on the question-namely, whether, instead of relations being established between the Imperial Government and these Colleges, it would not be better that the tie should exist between the County Councils and the Colleges, which would stimulate local interest. That was a matter which was too wide for discussion then; but he threw out the idea, in case it should become at any time the subject of their future consideration. It might be that the County Councils would throw their hearts into this work, as he believed they were doing in many parts of the country into the question of technical and other education, and for his part he should see no objection to any course that would tend to increase local interest in these Colleges.

IN several journals attention has lately been called to the fact that for women there exists at the present moment at Bedford College the very facilities for study which University College and King's College propose to offer when the present scheme for the development of their scientific teaching is carried out. Bedford College, one of the earliest established for women only, was founded as long ago as 1849 ; and when the University of London admitted women to its degrees, Bedford College students were the first to graduate there, while of those women who have since taken degrees in arts and science, a large proportion have belonged to the same institution. A new wing has just been added to the College, so that four separate laboratories are now open daily for the use of ! women desirous of carrying on practical work in biology, botany, chemistry, or physics. Special advantages are provided for those who have any bent for higher work or for original research. As the public opening of the new wing has been unavoidably postponed, the Council of the College desire it to be known that since Easter, 1890 , the new laboratories have been in full working order, and that they can now offer accommodation to a greatly increased number of women students.

AT a meeting of the Biological Society of Washington, on February 7, Mr. Charles D. Walcott, of the U.S. Geological Survey, announced the discovery of vertebrate life in the Lower Silurian (Ordovician) strata. He stated that "the remains were found in a sandstone resting on the pre-Palæozoic rocks of the eastern front of the Rocky Mountains, near Canon City, Colorado. They consist of an immense number of separate plates of placoganoid fishes, and many fragments of the calcified covering of the notochord of a form provisionally referred to the Elasmobranchii. The accompanying invertebrate fauna has the facies of the Trenton fauna of New York and the Mississippi valley. It extends into the superjacent limestone, and at a horizon 180 feet above the fish beds seventeen out of thirtythree species that have been distinguished are identical with species occurring in the Trenton limestone of Wisconsin and New York. Great interest centres about this discovery from the fact that we now have some of the ancestors of the great group of placoderm fishes which appear so suddenly at the close of the Upper Silurian and in the lower portion of the Devonian groups. It also carries the vertebrate fauna far back into the Silurian, and indicates that the differentiation between the invertebrate and vertebrate types probably occurred in Cambrian time." Mr. Walcott is preparing a full description of the stratigraphic section, mode of occurrence and character of the invertebrate and vertebrate faunas, for presentation at the meeting of the Geological Society of America, in August next. 